\title{
"LIVE OAK, WITH MOSS" AND "CALAMUS": TEXTUAL INHIBITIONS IN WHITMAN CRITICISM
}

\author{
Steven Olsen-Smith and Hershel Parker
}

THE "CALAMUS" SEQUENCE, first published in the third edition of Leaves of Grass (1860) after Whitman had written and dismantled a related shorter sequence called "Live Oak, with Moss," proved exalting and liberating to some late nineteenth-century readers of Whitman. But "Calamus" also proved troublesome to some of Whitman's admirers before and after his death, then proved problematical to critics in the first twothirds of the twentieth century, even though many readers may have cherished it privately in uncomplicated ways. The evidence is in the criticism: until after the Stonewall Riot and the first Gay Pride marches, very few critics seemed entirely comfortable writing about the "cluster," to use Whitman's term. Only in the last quarter century, after gay liberation and the rise of queer theory, have sexual inhibitions broken down to the point that all critics can talk more freely about "Calamus." But some equally inhibiting assumptions - textual and aesthetic, not sexual-have persisted, apparently not so much unacknowledged by the critics as unrecognized by them. Our purpose here is to further the liberation of criticism on "Calamus" by identifying and scrutinizing some of these still-closeted assumptions. Never claiming to do full justice to any particular discussion of "Calamus," we quote selectively so as to highlight patterns in Whitman criticism.

A very few Whitman critics, notably Edwin Haviland Miller, have insisted that there is "no narrative continuity" in "Calamus" and that nothing was gained from Whitman's rearrangement of various poems in the sequence over successive editions. ${ }^{1}$ In a similar spirit Robert J. Scholnick concluded that "Whitman was unable to find a way to unify the many diverse, sometimes contradictory themes of 'Calamus." 2 Most critics, however, took for granted that a cluster given an overall title, "Calamus," and consisting of poems dealing with the "theme" of "manly love" was open to explication as a coherent work of art within a larger work of art, the whole of the 1860 Leaves of Grass. Of critics who took the cluster as coherent, a good many contented themselves with modest claims. Howard J. Waskow was convinced that "the Calamus poet is far from careless"; instead, Whitman was "cautious and deliberate-con- 
scious of himself, his poetry, and his audience," so deliberate that Waskow could identify the "central poem" of the cluster, "Scented Herbage of My Breast." " Gay Wilson Allen observed that a "paradox of theme, imagery, and symbolism ran throughout" the cluster and also that a "sense of loneliness and longing for a responsive friend and/or lover runs throughout many of the "Calamus' poems." In the "necessity of comradeship," Jay Grossman found a "pattern" that informed "the 'Calamus' series at every level." 5 For James E. Miller, Jr., in the "very title" was the image that dominated the cluster; "the phallic-like calamus root image" permeated "the entire cluster." In much the same spirit Ezra Greenspan maintained that "Whitman had never before dealt with a single theme or mood sustained over a series of poems, as he was to attempt in these Calamus poems." ${ }^{7}$ Other critics likewise contented themselves with claims that Whitman kept pretty much to the same theme, idea, image, or some other element-modest enough claims.

Meanwhile, some Whitman critics made stronger claims for authorially structured unity and identified not merely consistency but actual "development" or "growth" in the "Calamus" poems. Leland Krauth found "a clearly discernible development," a "developing pattern" in which Whitman "works out the meanings of comradeship"; the pattern was equipped with a "turning point" and a "pivotal" poem ("Of the Terrible Question of Appearances"). ${ }^{8}$ According to Stephen A. Black, "Calamus" has a "fantasy-substructure"; as the section "develops," the "lovers become increasingly silent and intuitive." "George B. Hutchinson claimed that Whitman "deliberately developed the 'Calamus' section for larger purposes linked to the thrust of the 1860 edition as a whole." 10 Kerry C. Larson declared that "Calamus" "displays a growing sense of estrangement" from Romantic notions of transubstantiation. ${ }^{11} \mathrm{M}$. Jimmie Killingsworth assumed that "Whitman developed a language and the rudiments of a psychology by which homosexuals could be brought to self-awareness and by which same-sex friendship could form the basis for political action." 12 Tenney Nathanson identified a definite "movement" toward institutionalism. ${ }^{13}$ John E. Schwiebert identified in "Calamus" an "emotional movement" and "tension-generating movement." ${ }^{14} \mathrm{M}$. Wynn Thomas claimed that "the Calamus sequence as a whole achieved its published form only after Whitman had spent a great deal of time and energy deliberately fashioning poems of disparate origins into a single group." "15 Whitman was "a poem-builder" as well as "a house-builder" (36), and his assembling of the "Calamus" poems was "a branch of the construction industry" (37). Thomas complained about "a marked tendency to underestimate the considerable degree of deliberate choice and conscious control with which, as there is ample evidence, Whitman labored to compose both individual poems and the collection as a whole" (36). In criticism of "Calamus," praise such as 
we have just quoted tended not to be bolstered by close examination of particular stages of the "development" or "growth" these critics saw; indeed, critics sometimes seem to have made unquestioning use of terms that the original New Critics had applied only to tightly constructed poetry and fiction.

Throughout the heyday of the New Criticism, when it was common to praise literary structures in terms of near-mystical perfection, no Whitman critic made wildly extravagant claims for complexity of architectonics in the "Calamus" sequence. Nevertheless, Russell A. Hunt boldly testified to the "essential unity of theme of 'Calamus." 16 Whitman "thought of the poems in the 'Calamus' section as representing some sort of integral group," Hunt was sure, but Whitman's intention was not what counted most: "More important, however, than any inference about how Whitman thought of 'Calamus' is the fact that the hypothesis that the section is an organic whole leads to a fuller and richer reading of the poems themselves" (483). What counted most was the "fact" that a hypothesis of organic unity made a fruitful New Critical strategy. Critical strategy trumped biographical speculation about any coherent intention Whitman might have held.

At the same time, a New Critical bias against textual scholarship emerged in the vagueness critics showed as to the history of "Calamus," vagueness that allowed some to write as if the cluster had been all but static. Hunt declared that "Calamus" is one of the "sections of the 1860 Leaves of Grass which survived essentially intact the repeated and drastic revisions Whitman undertook between then and 1891" (483); Whitman had preserved "Calamus" "essentially unchanged through all the successive editions of Leaves of Grass" (493). It was enough for Hunt that Roy Harvey Pearce and James E. Miller, Jr., had established "that the alterations of 'Calamus' between 1860 and 1891 do not essentially change the nature of the section" $(484 \mathrm{n})$. (How much is required to change the nature of a sequence remained untested.) The critics' need for a stable text to explicate obviated any rival need for textual investigation.

Having little textual information and displaying little curiosity about any changes in "Calamus," many critics, relying on the widely available facsimiles of the third edition of Leaves of Grass (1860), wrote about "Calamus" as the original forty-five poem cluster. Other critics found consistency of theme and structural development equally present in the forty-five-poem sequence or in the final thirty-nine-poem sequence, without much concern for textual differences. Edward M. Wheat quoted from the 1965 Comprehensive Reader's Edition (which printed the thirtynine poem "Calamus"). Manifesting no awareness that the text differed from that in another edition, he made claims for the way "Calamus" and "Children of Adam" worked in the whole of Leaves of Grass: "containing 16 and 39 poems respectively," the two clusters were "crucial in 
the development of the book's epic narrative line" and were "also meant to transform the reader's views on personal freedom." ${ }^{17}$ Vivian R. Pollak identified "For You, O Democracy" as "the poem currently positioned as the fourth in the "Calamus' sequence." 18 Her use of "currently" to mean in the Bradley-Blodgett-Golden-White 1980 variorum edition of Leaves of Grass revealed a curious unexplored sense of textual contingency. With comparable casualness, Russell Hunt had explained (484n) that he used "the final, 1891-1892 edition as opposed to the 1860 edition largely because it is more generally available." Since those critics who cited the 1860 text tended not to bother to justify their choice on historical, biographical, or even aesthetic grounds, it looks as if convenience or availability often was a deciding factor in choices of text for citation and explication.

In the lack of ready textual information (in, say, cheap and clear facsimile reprints of all the editions of Leaves of Grass), it is no surprise to find that critics sometimes misspoke themselves. Leland Krauth in describing Whitman's "symbolic arrangement of the 1881-1882 edition" (147) said that poems 16, 21, 27, and 31 (in the 1860 numbers) were omitted because they were "not well integrated thematically" (149). Yet 16 was omitted from the 1867 edition and 21, 27, and 31 were all omitted from the 1871 edition, earlier than Krauth said they were omitted. Krauth further declared that in 1881-1882 poem 8 was omitted and "replaced" with "The Base of All Metaphysics" (150), but in fact 8 had already been omitted from the 1867 edition, while "The Base of All Metaphysics" was not added after 7 until 1871, so it never exactly "replaced" poem 8. M. Wynn Thomas claimed that it was in "Calamus" that Whitman "created, out of his lonely yearnings, the antithetical image of the self-sufficient live oak, standing in its pride of singleness"19; more precisely, though, Whitman actually first created this in the earlier twelve-poem sequence, "Live Oak, with Moss." Edward M. Wheat made this observation: "In 'Of the Terrible Doubt of Appearances,' the poet says that he cannot directly answer 'the question of appearances,' but in the following poem, 'The Base of All Metaphysics' is said to be the "dear love of man for his comrade, the attraction of friend to friend" (248). "Base" indeed follows "Terrible Doubt" in 1881, as it did in 1871 , but it had not done so in earlier editions. Here Wheat passed by the chance to claim that his citing the "deathbed edition" of Leaves of Grass was justified by Whitman's artistry in placing "Base" after "Terrible Doubt," whenever he did so.

Critics could hardly have been expected to speak precisely about the contents of different editions of Leaves of Grass when editors were still imprecise in so fundamental a matter as the use of the technical bibliographical term "edition." In the Comprehensive Reader's Edition of Leaves of Grass, Harold W. Blodgett and Sculley Bradley referred to "the successive nine editions of the poet's lifetime." ${ }^{20}$ In the New Walt 
Whitman Handbook (1975), Gay Wilson Allen identified only six textually significant editions in Whitman's lifetime (that is, after the 1855 edition, only five which contained Whitman's revisions or additions), ${ }^{21}$ a conclusion shared by Bradley, Blodgett, Arthur Golden, and William White in Leaves of Grass: A Textual Variorum of the Printed Poems ${ }^{22}$ and by Joel Myerson in Walt Whitman: A Descriptive Bibliography (1993). ${ }^{23}$ (Hunt, about the time the Handbook appeared, and Wheat, long afterward, were two of a good number who did not identify the form of "Calamus" in the 1892 "deathbed edition" as the form that had first appeared in 1881.)

It was Myerson who made it simple to differentiate among editions of "Calamus." Identifying only four true editions of Leaves of Grass containing the cluster, he helpfully listed titles of the "Calamus" poems in each edition from 1860 to 1881 . Now it is easy to derive such basic information as this from Myerson:

-Three poems in the 1860 edition $(8,9,16)$ were dropped from the "Calamus" section in the 1867 edition (and \#5 shortened, and \#44 moved up to follow 31).

-Four more poems $(17,21,27$, and 31$)$ were dropped from the 1871 edition.

-38 of the 45 poems of the 1860 edition persisted (\#5 shortened in 1867, \#19 shortened in 1871) through every subsequent edition.

-In 1871 "The Base of All Metaphysics" was added after \#7; and the poems after \#19 (in its shortened form) came in this order: 20, 22, 23, 24, 25, 26, 30, 44, 28, 32, 29, $33,37,35,36,34,38,39,40,41,42,43,45$.

-In the 1881 edition Whitman reversed \#4 and shortened \#5, and the sequence of the poems after the shortened \#19 was again altered: 20, 22, 23, 24, 25, 28, 26, 30, 44, $33,29,37,36,34,32,35,39,42,38,41,43,40,45$.

Much of this information had been available in the New Walt Whitman Handbook and the "Cluster Arrangements" section of the Textual Variorum, but scholarship has to be packaged conveniently if critics are going to use it. Now, after Myerson, even a critic without access to a major research library readily can determine the presence, absence, or the relocation of a given poem in editions after 1860 (although the critic who wanted to talk about variants in the text of a given poem would still need to go to the Textual Variorum or to the actual editions identified by Myerson).

In the light of Myerson's information, it seems stranger than before that no one had rigorously read the 1860 "Calamus" against "Calamus" in 1867 and in 1871 and in 1881. In fact, no critic ever undertook the basic task of seeing what old meaning is altered and what new meaning is created when a given poem, revised or not, is removed from one context and placed down into another. Such questions have been asked neither in terms of local effects (on the way a poem fits into the immediate context, the poem or poems preceding or following it) nor in terms of the way a poem fits into the "whole" of the sequence, whatever po- 
ems (in whatever forms) constituted that sequence. No one who took the 1860 "Calamus" as embodying some degree of aesthetic unity went on to ask if the subsequent alterations in the sequence embodied a series of new unities in 1867, in 1871, and in 1881, each edition being equally unified, whatever the number of the poems and however varying their forms and their sequences. ${ }^{24}$ Other questions will occur to anyone who reflects on the logistics of the reorderings, especially those in 1871 and 1881 . Myerson complicates our lives as critics by confronting us with such responsibilities. At the least, his classifications of successive editions and his listing of the successive contents of the "Calamus" cluster suggest forcibly that as critics we cannot responsibly talk about the "Calamus" poems without being clear to ourselves and others just what poems we are talking about.

Yet the implications of Myerson's evidence for criticism on "Calamus" may not be as significant as information not in Myerson at all but rather stored and generally ignored in Fredson Bowers's 1953 and 1955 studies: information about the relationship between "Calamus" and the earlier twelve-poem "Live Oak, with Moss" sequence that Whitman dismantled in order to scatter the poems here and there in the "Calamus" section of the third (1860) edition of Leaves of Grass. ${ }^{25}$ For four decades after Bowers first published "Live Oak, with Moss," critics seldom said much at all about the sequence, and the little that was said tended to be inexact. For example, Gay Wilson Allen said that the group "Enfans d'Adam" was "an afterthought, growing not from an inner compulsion but used for the strategic purpose of balancing 'Calamus'-or more accurately the cluster of twelve poems first called 'Live-Oak Leaves,' before Whitman had thought of his calamus plant symbol." ${ }^{26}$ Allen knew perfectly well that "Live-Oak Leaves" was not the "first" or earliest known name of the cluster, for, as Bowers discovered, the earliest known title was "Live Oak, with Moss." Later Whitman inscribed a new title, "Calamus Leaves," above the old one, but that fact does not necessarily mean that there was no intermediate title. Allen quotes from notes in which Whitman used "Live-Oak Leaves" to refer either to the twelvepoem sequence or to an expanded group of poems on "the passion of friendship for men"-but Whitman may have made these notes before or after making the change of "Live Oak, with Moss" to "Calamus Leaves." For all we know at this point, Whitman could have used "LiveOak Leaves" and "Calamus Leaves" interchangeably for a time, after he had begun to expand the "Live Oak" sequence into what became "Calamus." Similarly, Arthur Golden blurred the distinction between the original twelve-poem sequence "Live Oak, with Moss" and the later "Calamus Leaves" and "Live-Oak Leaves." Because Whitman crossed out "Live Oak, with Moss" as a title and wrote "Calamus-Leaves" above that title, Golden assumed that the substitution amounted to a re-titling 
of the twelve-poem sequence, whereas Fredson Bowers's evidence had indicated that the re-titling was associated with an expansion of the contents of that section. ${ }^{27}$ David Cavitch said that at an early stage in the composition of the "Calamus" poems Whitman "toyed with arranging twelve of them into a cluster resembling an Elizabethan sonnet sequence." 28 Yet Bowers's evidence shows that Whitman did not "toy" with so arranging the poems - he actually arranged them that way. For the 1990 revision of his Twayne Walt Whitman, James E. Miller, Jr., did not list the "Live Oak" sequence in the index among Whitman's poems, although he did mention it in the text (and Miller did lay out the sequence in his earlier $A$ Critical Guide to Leaves of Grass). ${ }^{29}$ Still more curiously, "Live Oak, with Moss" is not listed in the "Index to Whitman Poems Cited" in The Continuing Presence of Walt Whitman, even though Alan Helms's article in the last section of that book is entitled "Whitman's 'Live Oak with Moss"" (without the comma). ${ }^{30}$ Even after The Continuing Presence of Walt Whitman, we still have the continuing absence of "Live Oak, with Moss." Surveying this situation, Hershel Parker commented that critics had tended "to treat the sequence almost as if it had not quite existed," as if "Live Oak, with Moss" had been "almost hypothetical," not real. ${ }^{31}$

To some extent, critics have found it very hard to acknowledge the existence of "Live Oak, with Moss" simply because it was not and is not available in any edition of Whitman's poetry. Bowers printed the sequence in Studies in Bibliography and he printed the individual poems scattered in different order through Walt Whitman's Manuscripts (in conjunction with their revised versions in "Calamus"), but neither Bowers nor anyone else printed "Live Oak" in a comprehensive edition of Whitman's poetry. Parker in 1994 printed it in the Whitman selections in the Fourth Edition of the Norton Anthology of American Literature, but such a printing in a classroom anthology does not have the air of authority that a printing in an edition of Whitman's poems would have. ${ }^{32}$ Whatever the reasons, Whitman critics for many years have treated "Live Oak, with Moss" in a gingerly fashion, if not quite as if it had been "hypothetical."

Even critics who accepted Bowers's and Allen's early opinion that the original sequence was coherent have rarely been much concerned about the subsequent scattering of the "Live Oak" poems throughout "Calamus." James E. Miller, Jr., found "no clear narrative plot" in the sequence and argued that "the fact that all twelve of these poems were scattered throughout the 'Calamus' section in 1860 suggests that the earlier sequence was somewhat tenuous"(59). Arthur Golden, on the other hand, acknowledged that the twelve poems had made up a "highly revealing sequence," and even allowed that when distributed in "Calamus" the "immediate poetic impact gained from the concentration of twelve such poems in one cluster was thereby considerably diminished" 
(xxvi). Yet he quickly reassured himself by deciding that two of the poems "added" to the 1860 Calamus group were "every bit as revealing and evocative as poems I-XII" (xxvi). Because these two, and some others, plus the redistributed twelve, in 1860 gave "an explicit account of Whitman's responses to his involvement with 'manly love', whatever their distribution in the forty-five poem cluster," Golden concluded that "little really was lost" (xxvii). Similarly, Betsy Erkkila treated the original twelve poems as readily dispersable units: "By interspersing the original twelve love poems of 'Live Oak with Moss' [no comma] among poems of a more public nature, Whitman sought to reconnect his private homosexual feeling with the public culture of democracy." 33 Ezra Greenspan reflected on what had taken place in the formation of "Calamus," particularly Whitman's discovery of the "cluster," "the structuring principle he had been looking for years to work into his book" (202). By 1860, Greenspan said, "the cluster had grown to forty-five poems, and the task of organizing so many poems written over a three-year period required an act of considerable editing"; the "homogenization of the poems necessitated by the editorial process was naturally to obscure some of the differences between the earlier and later poems"(202). A little later Helms and Parker rued the obliteration of the narrative of "Live Oak, with Moss," but for these earlier critics, the alteration and dispersal of the poems was no great loss.

In the last two decades, a few critics at last have attempted to come to terms with the twelve-poem sequence. Summarizing Bowers's 1955 evidence about the origin of the "Calamus" section in the "Live Oak, with Moss" sequence, Stephen A. Black saw the twelve poems as containing a "coherent narrative" (187), the record "of a profound crisis in Whitman's attitude about continuing to write poetry" (186). Black's reading of "Live Oak, with Moss" was in accordance with his rejection of Edwin H. Miller's treatment of Whitman, which he saw as "overtly and actively homosexual and generally conscious of the sexual meanings of his poems" (5). Instead, Black claimed that "Whitman tended to keep hidden from himself both his homosexual impulses and his sexual confusions" (5), and that the "Live Oak" poems were about autoerotic fantasy. He recognized that the "'Enfans d'Adam' cluster of 1860 descends as directly from 'Live Oak, with Moss' as does 'Calamus'”' (212), but he did not read "Calamus" in relation to the twelve "Live Oak" poems-indeed, he skipped each of the twelve every time he came to one of them in his discussion of "Calamus." Martin F. Kearney in "Whitman's 'Live Oak, with Moss': Stepping Back to See,"34 was another pioneer critic of "Live Oak, with Moss" as a separate sequence, one which he thought "structurally superior" to "Calamus" (40). Kearney's opening comments consisted largely of a restatement of Bowers's discoveries, and his poem-by-poem analysis was not strenuous, but his conclusion was by far the most challenging any critic had 
offered. "Live Oak" expressed "the theme of adhesiveness" better than "Calamus" did because it did so "within a tightly structured framework" which provided "wholeness and balance." James Perrin Warren listed the location of the twelve "Live Oak" poems within "Calamus" and worked with Bowers's evidence that "Live Oak, with Moss" was the basis for "Calamus" (and subsequently led to the composition of the "Children of Adam" poems), but he did not read "Live Oak, with Moss" and did not talk about the revisions of the "Live Oak, with Moss" poems for their inclusion in "Calamus." ${ }^{35}$ Robert J. Scholnick acknowledged "Live Oak" as the "core of the "Calamus' sequence," noting that when Whitman put the twelve poems into "Calamus," he "devised a new ordering scheme for the entire body" (60). Although Alan Helms overlooked these early discussions when he claimed that the sequence had been "virtually ignored" until the publication of his own essay in The Continuing Presence of Walt Whitman (185), his was by all odds the closest reading yet: the problem was that it was not a reading of the original "Live Oak, with Moss."

In his essay, Helms printed and discussed what he called "Live Oak with Moss" (without the comma), ${ }^{36}$ but his text was spurious, based not on the original sequence Bowers had printed but on the twelve poems in their revised forms taken from "Calamus" and put back (by Helms) into their "Live Oak" order. In "The Real 'Live Oak, with Moss': Straight Talk about Whitman's 'Gay Manifesto," Parker argued that here was a case where it really made a difference what text a critic was explicating - the difference between the original frank and confident narrative and the revised poems in which Helms found a "narrative of homophobic oppression" (190). Helms and Parker were not concerned to analyze the 1860 "Calamus" cluster, but each of them echoed and expanded some of Bowers's opinions about the relationship between the "Live Oak" poems and the "Calamus" section of the 1860 edition of Leaves of Grass. Without noting Whitman's revisions of the twelve "Live Oak" poems for inclusion in "Calamus," Helms perceived that Whitman had reordered the poems "in such a way that he obliterated the narrative they contain" (186). As far as Helms was concerned, the resulting new Calamus sequence was "shot through with a sense of fear and impending danger" (193) and "framed" (194) by incoherence. Parker went so far as to declare that the 1860 Calamus section seemed to have been conceived, later than the "Live Oak" sequence, "as a way of salvaging" those poems (151-152) even while, as Helms had said, obliterating the narrative. Neither quite said so, but Helms and Parker implied that Whitman had been more concerned with disguising the too-obvious homosexual love story of "Live Oak, with Moss" than creating a new unity in what became a 45-poem cluster in the 1860 Leaves 
of Grass. Kearney had anticipated them in his comments on James E. Miller, Jr.'s labeling the structure of "Calamus" symphonic: "Such criticism might be a kind way of saying that Whitman periodically loses sight of his theme of adhesiveness in 'Calamus' only to return to it unexpectedly in one disguised form or another." Since Kearney's essay is difficult to lay hands on, we quote the rest of his summation so as to have it on record: "Indeed, if 'Calamus' is as a symphony with an evasive and erratic leitmotif, 'Live Oak, with Moss' is as a skillfully crafted, harmonic Kunsterlied wherein the man-poet intones clearly his anthem of universal brotherhood" (49).

Helms's and Parker's articles seem sure eventually to have consequences for criticism, particularly since "Live Oak, with Moss" will remain in the Fifth Edition of the Norton Anthology of American Literature and will, we predict, be included in other classroom anthologies. At last, the sequence is being taught, particularly at the college level, and will be explicated more often in print, for success in the classroom always leads some teachers to write about their experiences. And the sequence will be known in its original text, for, as Parker said at the end of his 1996 article, Whitman matters too much to let "Live Oak with Moss" drive out the newly reclaimed "Live Oak, with Moss." At present "Live Oak" has a long way to go before becoming as canonical as "Crossing Brooklyn Ferry" or "Vigil Strange," but its passionate advocates will not let it disappear again from Whitman criticism. Another reprinting or two in a widely used anthology, close readings by two or three critics with institutional and personal clout, perhaps a retrospective autobibliographical essay on "Live Oak," "Calamus," and "Children of Adam," and canonization is assured.

Yet even today, almost half a century after Bowers's discovery of "Live Oak, with Moss," even the best Whitman critics still have not shaken off New Critical assumptions in regard to "Live Oak, with Moss" and "Calamus." Critics assume that Whitman must have bestowed new intentionality on the "Live Oak, with Moss" poems when he dispersed revised versions of all of them among 33 new poems in the 1860 "Calamus," but these critics have not scrutinized the 1860 variants in an effort to determine if any of Whitman's revisions of the "Live Oak" poems were designed to make them fit into their new placements in "Calamus." No critic has commented on the problems that arise when, for instance, a poem that coherently leads into another poem in "Live Oak" occurs in "Calamus" after the poem it originally preceded. In all the talk of "unity" and "development" in the 1860 "Calamus," critics have ignored the problems that arise from a rigorous poem-by-poem reading, such as the incongruity of the dark "Hours continuing long" (poem 9), which follows and precedes much more optimistic poems. Recognizing the problem as he worked over the 1860 text, Whitman dropped "Hours continuing long" from later editions. ${ }^{37}$ His removing this single most 
disruptive poem from "Calamus" suggests that other alterations of "Calamus" might also have been purposeful, yet no critic has read the 1860 sequence against the 1867 , the 1871 , and the 1881 sequence, so as to see whether the later reorderings might have progressively improved the coherence of the cluster.

These still-current textual/aesthetic premises perpetuate some dangerous critical assumptions: that a completed sequence like "Live Oak" is hardly more than hypothetical if the writer does not get it into print; that Whitman could not lose anything essential by taking apart a coherent sequence and scattering the constituent poems among many more poems; that any varying combination of poems in varying states is coherent as long as Whitman printed the combinations under the name "Calamus" (whether in 1860, 1867, 1871, or 1881); that revisions of "Enfans d'Adam" (or "Children of Adam") kept rough pace aesthetically with revisions of "Calamus." Now that sexual inhibitions have been shattered, such still-closeted textual/aesthetic assumptions need to be exposed. Once exposed, some of them will also shatter, and critics will be liberated to ask fresh questions about all three separately titled sequences- "Live Oak, with Moss" (in its unique authorial form) and "Calamus" and "Children of Adam" in their varying authorial formsif not about Leaves of Grass "as a whole," whatever the "whole" consists of.

\section{University of Delaware}

\section{NOTES}

1 Walt Whitman's Poetry: A Psychological fourney (Boston: Houghton Mifflin Company, 1968), 150.

2 “'This Terrible, Irrepressible Yearning': Whitman's Poetics of Love," in American Declarations of Love, ed. Ann Massa (New York: St. Martin's Press, 1990), 65.

3 Whitman: Explorations in Form (Chicago: University of Chicago Press, 1966), 9091.

4 Walt Whitman (Detroit: Wayne State University Press, 1969), 98, 99.

5 “'The Evangel-Poem of Comrades and of Love': Revising Whitman's Republicanism," ATQ 4 (September 1990), 208.

6 Leaves of Grass: America's Lyric-Epic of Self and Democracy (New York: Twayne Publishers, 1992), 62.

7 Walt Whitman and the American Reader (Cambridge: Cambridge University Press, 1990), 200.

8 "Whitman and his Readers: The Comradeship Theme," Walt Whitman Review 20 (December 1974), 148, 149, 150.

9 Whitman's fourneys into Chaos: A Psychoanalytic Study of the Poetic Process (Princeton: Princeton University Press, 1975), 208, 198. 
10 The Ecstatic Whitman: Literary Shamanism $\mathcal{E}$ the Crisis of the Union (Columbus: Ohio State University Press, 1986), 98.

11 Whitman's Drama of Consensus (Chicago: University of Chicago Press, 1988), 174.

12 Whitman's Poetry of the Body (Chapel Hill: University of North Carolina Press, 1989), 97.

13 Whitman's Presence: Body, Voice, and Writing in "Leaves of Grass" (New York: New York University Press, 1992), 417.

14 The Frailest Leaves: Whitman's Poetic Technique and Style in the Short Poem (New York: Peter Lang, 1992), 25.

15 "Whitman's Achievements in the Personal Style in Calamus," Walt Whitman Quarterly Review 1 (December 1983), 38.

16 "Whitman's Poetics and the Unity of 'Calamus," American Literature 46 (January 1975), 484.

17 "Walt Whitman's Political Poetics: The Therapeutic Function of 'Children of Adam' and 'Calamus,'” Midwest Quarterly 31 (Winter 1990), 237.

18 "Death as Repression, Repression as Death: A Reading of Whitman's 'Calamus' Poems," Walt Whitman of Mickle Street: A Centennial Collection, ed. Geoffrey M. Sill (Knoxville: University of Tennessee Press, 1994), 191.

19 The Lunar Light of Whitman's Poetry (Cambridge: Harvard University Press, 1987), 220 ,

20 New York: New York University Press, 1965, xxvii.

21 New York: New York University Press, 1975, 147.

22 New York: New York University Press, 1980, 1:xxi.

23 Pittsburgh: University of Pittsburgh Press. Myerson also includes as separate "editions" of Leaves the 1873 English pirated edition and, anomalously, the 1886 English selection of Whitman poems, edited by Ernest Rhys. Still, Myerson confirms that Whitman himself was involved in only six major editions of Leaves.

24 For commentary on Oscar Lovell Triggs's essay in the Complete Writings, "The Growth of 'Leaves of Grass,"' see Leaves of Grass: A Textual Variorum of the Printed Poems, Volume I: Poems, 1855-1856, ed. Sculley Bradley, Harold W. Blodgett, Arthur Golden, William White (New York: New York University Press, 1980), xi. After quoting Gay Wilson Allen's comment that the initial assumption on which Triggs's essay was based had "prevented genuine critical analysis," the editors of the Textual Variorum continued: "This assumption was that Whitman's structure for the completed Leaves of Grass (essentially the 1881 edition plus later annexes) had been prefigured from the start, almost mystically so, a concept which the poet himself sometimes supported and sometimes frankly disavowed, and which his disciples illustrated by two rather contradictory metaphors, the organic one of the growing tree, and the architectural one of the precise design for a cathedral. We know now that the reality was otherwise. Quite simply, Whitman altered Leaves of Grass from edition to edition as his own views changed." They continued with this reflection: "Simplistic assumptions about the growth of Leaves of Grass momentarily encouraged studies of its structure more distinguished by theorizing than by scrutiny of its actual editorial history." It is just such studies that we scrutinize in this essay. 
25 "Whitman's Manuscripts for the Original 'Calamus' Poems," Studies in Bibliography 6 (1953 [for 1954]), 257-265; Whitman's Manuscripts: “Leaves of Grass” (1860): A Parallel Text (Chicago: University of Chicago Press, 1955). One of the most conscientious and perceptive attempts to explicate the 1860 "Calamus" poem-by-poem is in Walt Whitman's Poetry, but Edwin H. Miller handicapped himself by not taking any account of information already available about the relation of "Live Oak, with Moss" to both the "Calamus" and the "Enfans d'Adam" clusters.

26. The Solitary Singer: A Critical Biography of Walt Whitman (1955; rev. New York: New York University Press, 1967), 250.

27 Walt Whitman's Blue Book: The 1860-61 "Leaves of Grass" Containing his Manuscript Additions and Revisions (New York: New York Public Library, 1968), 2:xxiixxvii.

28 My Soul and I: The Inner Life of Walt Whitman (Boston: Beacon Press, 1985), 131.

29 Walt Whitman, Updated Edition (Boston: Twayne Publishers, 1990), 114; A Critical Guide to Leaves of Grass (Chicago: University of Chicago Press, 1957), 57-59.

30 The Continuing Presence of Walt Whitman: The Life after the Life, ed. Robert K. Martin (Iowa City: University of Iowa Press, 1992), 257; Alan Helms, "Whitman's 'Live Oak with Moss,'” in Continuing Presence, 185-205.

31 “The Real 'Live Oak, with Moss': Straight Talk about Whitman's 'Gay Manifesto,"” Nineteenth-Century Literature 51 (September 1996), 151, 152.

32 The Norton Anthology of American Literature, 4th Ed., ed. Nina Baym, et al., 2 vols. (New York: W. W. Norton and Company, 1994), 1:2,097-2,101. In a reader's report on a proposal for a new edition of the Norton Critical Edition of Leaves of Grass, Parker has suggested that any new editor be urged to include "Live Oak, with Moss" and to place it before any selection from "Calamus."

33 Whitman the Political Poet (Oxford: Oxford University Press, 1989), 179.

34 Innisfree 7 (1987), 40-49.

35 Walt Whitman's Language Experiment (University Park: Pennsylvania State University Press, 1990), 195-196.

36 There has been confusion over the comma ever since Bowers identified the sequence. Even though Bowers makes clear (92) that Whitman's original manuscript title was "Live Oak, with Moss." (including both a comma and a period), he carelessly drops Whitman's punctuation when he refers to the sequence in his introduction (lxv, lxxi). A number of critics have repeated Bowers's mistake.

37 Whitman marked "Hours continuing long" "Out for revision"; see Walt Whitman's Blue Book, ed. Arthur Golden (New York: New York Public Library, 1968), 1:355. If Parker is right in suggesting that the 1860 "Calamus" section was conceived as a way of salvaging "Live Oak, with Moss" regardless of damage to the narrative, it would follow that in preparing the first edition of "Calamus" Whitman was so intent on getting all the "Live Oak" poems into the sequence, however scattered, that he did not recognize just how disruptive "Hours continuing long" was in its new context. Whitman's removing "Hours continuing long" indicates that after he had the 1860 edition in hand he became able to put the sequence "Live Oak, with Moss" out of his mind and to focus on "Calamus" as a sequence in its own right, one worth revising. 